\title{
Zsuzsa Febér:
}

\section{SHELLEY: \\ "PIERCING THE INFINITE SKY"}

The wilderness has a mysterious tongue

Which teaches awful doubt.

In his poem written in 1816 Shelley presents his dualistic world view in a rather dense and powerful symbol. 'Mont Blanc'1 displays its theme through description converted into symbolism. There is a division to the scenery described. The borderline is the veil of clouds which hides from our sight what is beyond. What is below is referred to in a detailed description what is beyond is hinted at in interrogative sentences, that scenery is a mystery and remains a mystery:

Is this the scene

Where the old Earthquake-daemon taught her young

Ruin? Were these their toys? or did a sea

1 English Romantic Writers, ed. David Perkins. New York, Chicago: Harcourt, Brace \& World, 1967: 968. 
Of fire envelop once this silent snow?

He describes two different types of scenery. What is below, the "Many coloured, many voiced vales" is a diverse scene with "wild woods", mountains, waterfalls, "a vast river" and rocks, with caves and caverns. There is a multitude of images presented:

The fields, the lakes, the forests, and the streams,

Ocean, and all the living things that dwell

Within the deadal earth; lightning, and rain,

Earthquake, and the fiery flood, and hurricane,

The ever-changing quality of the scene is emphasized. There are constant shiftings in the "universe of things". With the four repetitions of the time adverbial Shelley stresses the time aspect:

Now dark - now glittering - now reflecting gloom -

Now reflecting splendour, ...

$$
\text { (1. 3-4.) }
$$

The whole scene is constantly darkening and lightening:

Thou many-coloured, many voiced vale, Over whose pines, and crags, and caverns sail

Fast cloud-shadows and sunbeams: aweful scene,

We can conclude that in the description of the scenery the time aspect and dynamism are emphasized with all the verbs denoting dynamic movements: "leap", "bursts and raves", "swinging".

All the living things of this realm are subject to the process of life and death. 
The limits of the dead and living world,

Never to be reclaimed. The dwelling-place

Of insects, beasts, and birds becomes its spoil;

Their food and their retreat for ever gone,

So much of life and joy is lost. The race

Of man flies away in dread; his work and dwelling

Vanish, like smoke before the tempest's stream,

And their place is not known.

All things that move and breathe with toil and sound

Are born and die; revolve, subside, and swell.

But in contrast to all that there exists a separate realm beyond, completely different of quality.

Power dwells apart in its tranquility,

Remote, serene, and inaccessible:

There is an ultimate power which transcends the vale of this-wordly existence. The sensual experiences characteristic of the sphere beyond the film of clouds are completely different from those described so far. There is "calm darkness" there and "voiceless lightning", "winds contends silently there". Different qualities do not exist in multiplicity, but they seem to emerge: the wind's "breath" is silent, the snowflakes "burn in the sinking sun".

Mont Blanc yet gleams on high: - the power is there,

The still and solemn power of many sights,

And many sounds, and much of life and death,

In the calm darkness of the moonless nights, 
In the lone glare of the day, the snows descend Upon that Mountain; none beholds them there, Nor when the flakes burn in the sinking sun, Or the star-beams dart through them:-Winds contend

Silently there, and heap the snow with breath

Rapid and song, but silently! Its home

The voiceless lightning in these solitudes

Keeps innocently, and like vapour broods

Over the snow.

$$
\text { (1. 127-139.) }
$$

The 'Mont Blanc' can be interpreted as drawing on the Platonic system. Plato also deciphers different spheres where there are different laws operating. Plato contrasts two kinds of motions: one characteristic of the phenomenal world and the other one of the ideal world; one is begotten and destructible, the other one unbegotten and indestructible. And that unbegotten existence functions as an infinite source. 2 The poem can be taken as the Platonic metaphysics transformed into a symbolic scenery. The two worlds divided by the borderline of the clouds can be interpreted as the phenomenal and the ideal realm of the Platonic system. The poem attempts to convey or elucidate an intuition of the Ultimate Being or the power of the cosmos. This power both transcends and ascends into our world. The "infinite sky" which is pierced solely by the snow-capped peak of Mont Blanc seems to be synonymous with the divinely order, in other words, with God, the prime source of everything:

The Secret strength of things

Which governs thought, and to the infinite dome

Of Heaven is as a law inhabits thee.

2 Platon: Works, in: Great Books of the Western World VII., ed. Robert Maynard Hutchins. Chicago, London: William Benton, 1952: 682. 
Such a content of the mountain symbol had also been expressed in ancient cultures like in the Greek mythology gods reside on Mount Olympus or we can also mention to Biblical references to the sacred mountain. Two examples of the poets who received divine inspiration while on a mountain are Jesus (Sermon on the Mount: Matthew 5) and Moses (Ten Commandments: Exodus 19). The mountain is seen as a connection between the mundaine and the supramundaine: "The Sacred Mountain - where Heaven and Earth meet - is situated at the center of the world. Every temple or palace - and, by extension, every sacred city or royal residence - is a Sacred Mountain, thus becoming a Center." 3

The mountain mediates between the two states of existence the this-wordly and the divine, a place where a transcendental experience can be encountered. This symbolic mountain top, as the abode of the divine, is comparable to the sources of wisdom from which the knowledge radiates in all directions like rivers that fertilize the land.

In the poem discussed the river Arve, which runs from the mountain top through the Alpine valley, affords a crucial link to Power. The river is pervaded with the qualities present at that inaccessible height:

Thy caverns echoing the Arve's commotion,

A loud, lone sound no other sound can tame;

Thou art pervaded with that ceaseless motion,

Thou art the path of that unresting sound -

The unintelligible Power fuses into something material and exists within it through likeness, through resemblance, through analogy:

Where Power in likeness of the Arve comes down

From the ice-gulfs that gird his secret throne,

3 Mircea Eliade: History: The Myth of the Eternal Return, New York, 1954: 12. 
The river originates from beyond the film of clouds, thus participates in the life there and carries its images. In Defence 4 he also expresses his assumption that there is a "permanent analogy of things by images which participate in the life of truth;" "the rhythmical elements of a poem are the echo of an eternal music." There are two further symbols associated with the river in the poem. One of them is the lightning which is suggestive of illumination:

[The river]

Bursting through these dark mountains like the flame

Of lightning through the tempest;

The other corresponding symbol is the rainbow:

Thine earthly rainbows stretched across the sweep

Of aethereal waterfall,

The rainbow is a reconciliation symbol, what is best known for its mention in the Bible. We are told in Genesis: "And God said, I do set my bow in the cloud, and it shall be for a token of a covenant between me and the earth. And it shall come to pass, when I bring a cloud over the earth, that the bow shall be seen in the cloud." (Genesis 9:13-14.) This bow represents the higher mind and is a link between God and man. By these two correspondig symbols the function of the river as a mediator, a divine messenger is emphasized.

J. A. Notopoulos says:

Mont Blanc is symbolic of Power, 'he secret strength' which governs thought and is the law to the universe; the various streams that flow from the mountain into one majestic river are symbolic of the temporal experiences that flow through the human mind. The use of a stream for a symbol is ... natural metaphysical symbol, as may be seen from its use by Coleridge in 'Kubla Khan'. ...The mind is endowed with a power which it derives from secret 'springs' are symbolic of a power

4 English Romantic Writers: 1075. 
emanating from the mind's immortal and ivine heritage. The effusion of the external universe with the stream of the soul may be interpreted as a Platonic conception of the mind.

(The Platonism of Shelley. Oxford, Durham: Clarendon, 1949: 207)

In the following chapter we shall consider how divine images are perceptible by the human mind.

II.

First we should attempt to interpret the symbolism of the poem in relation with human cognition. The mountain is a general cross-cultural symbol for the aspiration to transcend one's little self. The process of the ascent is a spiritual pursuit, a quest for an elevated vantage point which gives an exhilaration of the view.

Some of Shelley's prose writings help us to understand the significance of the image that Mont Blanc is piercing through a veil of clouds which frustrates the vision. Shelley claims in his essay 'On Life' 5 that "The mist of familiarity obscures from us the the wonder of our being", which is a a very close reformulation of his statement in the Defence: "The veil of familiarity obscures from us the wonder of our being." The veil-metaphor is very commonly used in the Romantic movement to denote some kind of cognitive block which separates us from the comprehension of some higher ideals. One of the important aspects of Shelley's definition of poetry is that it

...strips the veil of familiarity from the world, and lays bare the naked and sleeping beauty, which is the spirit of its forms." Or elsewhere: "It makes us the inhabitants of a world to which the familiar world is a chaos. It reproduces the common universe of which we are portions and percipients, and it purges from our inward sight the film of familiarity which obscures from us our wonder of being. ... Poetry lifts the veil

5 English Romantic Writers: 1063. 
from the hidden beauty of the world, and makes familiar objects as if they were not familiar. 6

Jay Appelton, in "The Experience of the Landscape", discusses the role of horizon in landscape painting:

It is a matter of common experience that the arrival at the horizon is followed by an opening up of a further field of vision, and the contemplation of the horizon therefore stimulates the expectation that such an extension of the field of vision is probable. ${ }^{7}$

The poem begins and ends with the mind. It begins with a statement and ends with a question. The statement is about how the human mind perceives the the images of the everlasting universe; the question touched upon at the end is how far the human mind is capable of transcending the sense experience, if images like the mountain, the stars, the sea barely flow through the mind points towards, or if there is something which is beyond our direct apprehension.

And what were thou, and earth, and clouds, and sea, If to the human mind's imaginings Silence and solitude were vacancy?

$$
\text { (1. 142-144.) }
$$

This manner of the objects pointing beyond themselves and thus setting out a chain of thoughts which transcend the object itself is described in his essay 'On Life': "in a wide sense almost all familiar objects are signs, standing not for themselves, but for other in their capacity of suggesting one thought which should lead to a train of thoughts. ${ }^{n}$ The poem starts with the following lines:

The everlasting universe of things

Flows through the mind, and rolls its rapid waves,

Now dark - now glittering - now reflecting gloom -

Now reflecting splendour, where from secret springs

The source of human thought its tribute brings

6 English Romantic Writers: 1074-1077.

7 Jay Appelton: Romantic Horizons. Columbia: University of Columbia Press, 1990: 10.

8 English Romantic Writers: 1064. 
Of waters, -

Seemingly this image is very close to that of 'The Eolian Harp' by Coleridge, but it is significantly different. Coleridge pictures the mind as a box of strings placed at an open window, and it makes music as the wind passes through: the world of the human mind flows through man's mind and thus it creates supernatural harmonies:

And that if all animated nature

Be but organic harps diversely fram'd,

That tremble into thought, as over them sweeps

Plastic and vast, one intellectual breeze,

At once the soul of each, and God of all?

In Shelley's poem the mind cooperates with the ever changing images, it absorbs them but it is not a sublime experience.

... For the very spirit fails,

Driven like a homeless cloud from steep to steep

That vanishes among the viewless gales!

The vantage of the perceiver is limited. He does not seem to be able to surpass the threshold which separates us from a supernatural world. The horizon marks an impediment to the line of vision. That is what the "viewless gales" expression refers to.

By 1816 , then Shelley would argue that despite the near-universal belief in an ultimate cause-a belief he shares-our experience of causation is a human construction. We cannot know and represent an ultimate Power; the best we can do is follow 'Mont Blanc' the process of the mind's creation of cause and effect. 10

9 ibid. 399.

10 Richard Isomaki: "Interpretation and Value in 'Mont Blanc' and 'Hymn to Intellectual Beauty'", Studies in Romanticism Spring 1991, 70-86: 73. 
What is beyond the horizon does not seem to unfold to our awareness. The mountain top is a deserted place:

A desert peopled by storms alone,

Save when the eagle brings some hunter's bone, And the wolf tracks her there -

$$
\text { (1. 67-69.) }
$$

According to Shelley's view human mind is lacking the capacity for sustaining a clear apocalyptic vision:

My own, my human mind, which passively

Now renders and receives fast influencings,

Holding an unremitting interchange

With the clear universe of things around.

$$
\text { (1. 37-40) }
$$

This parallels the idea put forth in the Defence: "...for the mind in creation is as a fading coal, which some invisible influence, like an inconstant wind, awakens to transitory brightness; "11 the insight into some spiritual realm is either a feeble momentary experience or takes place in a state of conscious-ness when we are not fully aware of the it:

Some say that gleams of a remoter world Visit the soul in sleep,-that death is slumber,

And that its shapes the busy thoughts outnumber

Of those who wake and live.-I look on high;

Has some unknown omnipotence unfurled

The veil of life and death? or do I lie

In dream, and does the mightier world of sleep Spread far around and inaccessibly Its circles?

The uncertainty of the experience is indicated by all the question marks. Shelley hints that our mind is not structured to fully comprehend a sublime

11 English Romantic Writers: 1084. 
experience consciously, the realm beyond the veil of clouds cannot be attained intellectually, only intuitively, to "feel":

Thou hast a voice, great Mountain, to repeal

Large codes of fraud and woe; not understood

By all, but which the wise, the great, the good

Interpret, or make felt, or deeply feel.

Shelley raises serious doubts if the "mystery of being can be penetrated". The throne of the ultimate being, the ultimate power is "inaccessible":

The wilderness has a mysterious tongue

Which teaches awful doubt.

\section{III.}

The definition of the poet, concerning such a sceptical view of human mind's cognition of sublime images should involve a number of paradoxes.

In the Defence Shelley describes imagination as the "faculty of approximation to the beautiful"12, and "Those in whom it exists in access are poets, in the most universal sense of the word[,]" as it is said further, the poets are those who express some kind of "indestructible order" which is close in definition to Truth, Beauty or Harmony. As it has been discussed, what can be appropriated for the "indestructable order" in the imagery of the 'Mont Blanc' poem is the "inaccessible" realm of the "infinite sky". The poet has no direct apprehension of it, he beholds the river which mediates between the two spheres:

Dizzy Ravine! And when I gaze on thee

I seem as in a trance sublime and strange

To muse on my own separate fantasy.

12 English Romantic Writers: 1073. 
Shelley applies Plato's famous cave simile, and he refers to the it as "the cave of the witch Poesy". Since the cave is the metaphorical expression the limitations of the human perception, this statement can be judged as a refutation of the high romantic claim of the poet as a seer. The cave only allows us to see shadows, ghosts, phantoms: some faint reflections:

In the still cave of the witch of Poesy, Seeking among the shadows that pass by, Ghosts of all things, that are some shade of thee, Some phantom, some faint image; till the breast From which they fled recalls them, thou art there! (1. 54 -58.)

He applies a rather plastic metaphor to express the intangibility of any kind of sublime experience. There are only intuitions of the ultimate Being, the Power of the cosmos, "some unsculptured image" issued forth:

Thine earthly rainbows streched across the sweep

Of the aethereal waterfall, whose veil

Robes some unsculptured image;

In another poem, 'The Sensitive Plant' there is a clear statement of Shelley's disbelief in the sense's capacity to convey the highest and permanent aspirations:

For love, and beauty, and delight,

There is no death nor change: their might

Exceeds our organs which endure

No light being themselves obscure. 13

In the Defence of Poetry he expresses that even if an internal quest for a glimpse into the ideal, into the "indestructible order" is completed, the "naked truth" is attained in the poet's mind, the experience cannot be communicated, since it cannot be materially realised. is incompatible with the corrupt "Few poets of the highest class have chosen to exhibit the beauty of their conceptions in its naked truth and splendour; and it is doubtful whether the alloy of costume, habit,

13 ibid. 1028. 
etc., be not necessary to this planetary music for mortal ears." In The Defence of Poetry Shelley gives considerable thought to his doubts about "the limitedness of the poetical faculty". He holds that an inside beyond the "painted veil", the mind is not capable of sustaining its inspiration.

...when composition begins, inspiration is already on decline, and the most glorious poetry that has ever been communi-cated is probably a feeble shadow of the original conceptions of the poet... For language is arbitrarily produced by the imagination and has relation to the thoughts alone; but all other materials, instru-ments, and conditions of art, have relations among each other, which limit and interpose between conception and expression. The former is a mirror which reflects, the latter is a cloud which enfeebles, the light of which both are mediums of communication. 14

Shelley claims that the highest aspirations of poets are basically not communicable since they are incompatible with the corrupt material of language. In the pursuit of the ideal separate the poet from the material world which creates an intense isolation. (This paradoxical aspect of the romantic quest is the subject for 'Alastor' which was written in the same year as the 'Mont Blanc'.) This sense of isolation creates in Shelley's conception of the poet's role. On one hand he formulates a purely idealistic attitude, on the other hand he refutes it. The aesthetics of the Defence is based on the moral benefits of the imagination. He holds that

A man to be greatly good must imagine intensely and comprehensively; he must place himself in the place of another and of many others; the pains and pleasures of his species must become his own. The great instrument of moral good is the imagination; and poetry administers to the effect by acting upon the cause. ... Poetry strengthens the faculty which is the organ of moral nature in the manner as exercise strengthens a limb ... it is a strain which distends, and then bursts the circumference of the reader's mind, and pours itself forth together with it into the universal element with which it has universal sympathy. 15

14 English Romantic Writers: 1084-1085.

15 ibid. 1076. 
As we have seen, the reader's psychology is quite an important focus for Shelley, and he maintains a rather pragmatic concept of poetry. The famous conclusion of the treatise also points towards this direction: "Poets are the unacknowledged legislators of the world." $\mathrm{He}$ contends that poets have an unrecognized and inevitable effect on the world. There is an unreconcilable contradiction between this view and the argument that the idealist is cursed with the dissatisfication communicating the very image of life expressed in its eternal truth. Shelley seems to have a clashing mentality. There are two sets of ideals influencing Shelley: Platonism and scepticism. C. E. Pulos, examining the relation of the two in Shelley's thinking, says:

... he no longer regarded Plato as 'sage', but had to come to see him ... as a kind of poetic dreamer. From this point of view regarding Plato Shelley was liberated, and liberated completely, by the influence upon him of the sceptical tradition. 16

Scepticism determines Shelley's basic divergence from Plato. Shelley has a view of the ideal: he desparately wants to see and communicate but he does not see it viable. Both views are present but it is impossible to incorporate them. It creates a clash.

\section{SUMMARY}

Shelley also can be interpreted as drawing on the dualism of the Platonic world view. The cosmos seems to be structured according to the a dichotomy of the phenomenal world and the realm of the ideals. Using the 'Mont Blanc' poem's imagery we might say that he sustains a belief that beyond the veil of the clouds there is an ideal world, which is beyond the confines of time and space. (In a sonnet written in 1818, 'Lift not the painted Veil', however, he raises doubts concerning the very existence of transcendent ideals thus expressing a complete disillusionment of the Platonic idealism:

16 The Deep Truth, Lincoln: University of Nebraska, 1954: 69. 
Lift not the painted veil which those who live Call Life; ...17

He states that the quest for some ultimate ideals can only be tragic and futile.) Shelley doubts if the human perceiver can surpass the borderline between the finite and infinite realms which is marked by the horizon. The human mind can only receive intuitions of the world beyond. And even that is a momentary and transitory experience.

Shelley's definition of the poet's role is rather contradictory. He maintains that the poet should apply to the highest ideals which, however, are too subtle to be grasped by the the medium of poetry. The state of the poet is admittedly paradoxical.

17 English Romantic Writers: 890. 